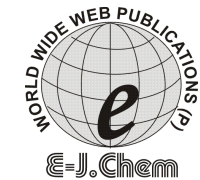

http://www.e-journals.net

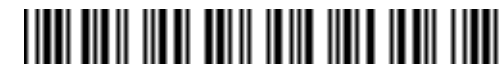

ISSN: 0973-4945; CODEN ECJHAO

E-Journal of Chemistry

Vol. 4, No.2, pp 284-286, April 2007

\title{
Toxic Effect of Cadmium on the Electrophoretic Protein Patterns of Gill and Muscle of Oreochromis mossambicus
}

\author{
K. MUTHUKUMARAVEL ${ }^{*}$, P. KUMARASAMY, \\ A. AMSATH and M.GABRIEL PAULRAJ ${ }^{\#}$ \\ P. G. and Research Department of Zoology, \\ Khadir Mohideen College, Adirampattinam-614 701, Tamil Nadu, India. \\ Email: kumar_phd_2003@yahoo.co.in \\ ${ }^{\#}$ Entomology Research Institute, \\ Loyola College, Chennai- 600 034, Tamil Nadu, India.
}

Received 21 November 2006; Accepted 28 February 2007

\begin{abstract}
The present study was carried out to determine the sub lethal toxic effects of the heavy metal cadmium on the electrophoretic protein fractions of gill and muscle tissues of Oreochromis mossambicus. Fishes were exposed to $10 \%$ sub lethal concentration $\left(96 \mathrm{~h} \mathrm{LC}_{50}\right)$ of cadmium for a period of 10 days. The protein fractions in the muscle of experimental fishes were found to be increased (twelve fractions) with respect to controls (eight fractions). The numbers of protein fractions in the gills of test fishes were found to be lesser than the control fishes. The results of the present study prove that cadmium affects the protein fractions in the tissues of fishes.
\end{abstract}

Keywords: Cadmium, toxic effects, protein, gill, muscle, Oreochromis mossambicus.

\section{Introduction}

Green revolution in Tamil Nadu (India) caused a multifold increase in the production of paddy. This achievement is due to the use of chemical fertilizers. Super phosphate is an important fertilizer used at the time of transplantation of the paddy seedlings. It was estimated to contain $3 \mathrm{mg}$ of cadmium in one $\mathrm{kg}$ of super phosphate ${ }^{1}$.

Cadmium, the most toxic and non-essential heavy metal has wide distribution in the earth's crust and aquatic environments. Due to its extensive uses in aquaculture, its concentration is increasing in the aquatic system ${ }^{2}$. With regard to heavy metals, less 
attention has been paid to the toxic effects of cadmium on fish. Information about the changes in biochemical constituents due to sub lethal effects of cadmium is still meagre. Fishes are the most important sources of protein in the world. The present study was undertaken to elucidate the effects of cadmium on the electrophoretic pattern in the gill and muscle of Oreochromis mossambicus exposed to $10 \%$ of $96 \mathrm{~h} \mathrm{Lc}_{50}$ concentration for a period of 10 days.

\section{Experimental}

O. mossambicus weighing approximately $10 \mathrm{~g}$ were collected from the ponds in and around Adirampattinam. They were kept for acclimatization in fish tank of 100 liter capacities containing well aerated pond water (salinity $1.5 \%$, dissolved oxygen $5.5 \mathrm{mg} / \mathrm{L}$ and water temperature $35{ }^{\circ} \mathrm{C}$ ) for a period of one week prior to the experiment. The toxicity tests were conducted following the method of Finney ${ }^{3}$. Based on the acute toxicity studies, the $\mathrm{LC}_{50}$ value of the test fish was found to be $2.5 \mathrm{mg} / \mathrm{L}$. The fishes were randomly divided into 2 equal groups of 10 individuals and one of the groups was maintained in pond water and served as control. The other group was exposed to $10 \%$ sub lethal concentration of $96 \mathrm{~h} \mathrm{LC}_{50}$ value of cadmium for 10 days. After their exposure, the control and experimental fishes were dissected out, the protein contents of muscle and gills were anlysed by SDS - PAGE under $6 \%$ stacking gel and $10 \%$ separating gel ${ }^{4}$.

\section{Results and Discussion}

Fish constitutes one of the major sources of protein for human beings ${ }^{5}$. The nutritional value of different tissues of fish depends on their biochemical composition like protein, amino acids, vitamins, mineral contents, etc. In the present study, sub lethal concentration of cadmium has showed variations on the electrophoretic patterns of proteins fractions in the muscle and gills of $O$. mossambicus. In the muscle tissues of cadmium exposed fish, four new protein fractions viz. $120 \mathrm{kD}, 80 \mathrm{kD}, 62 \mathrm{kD}$ and $37 \mathrm{kD}$ were observed (Figure 1).

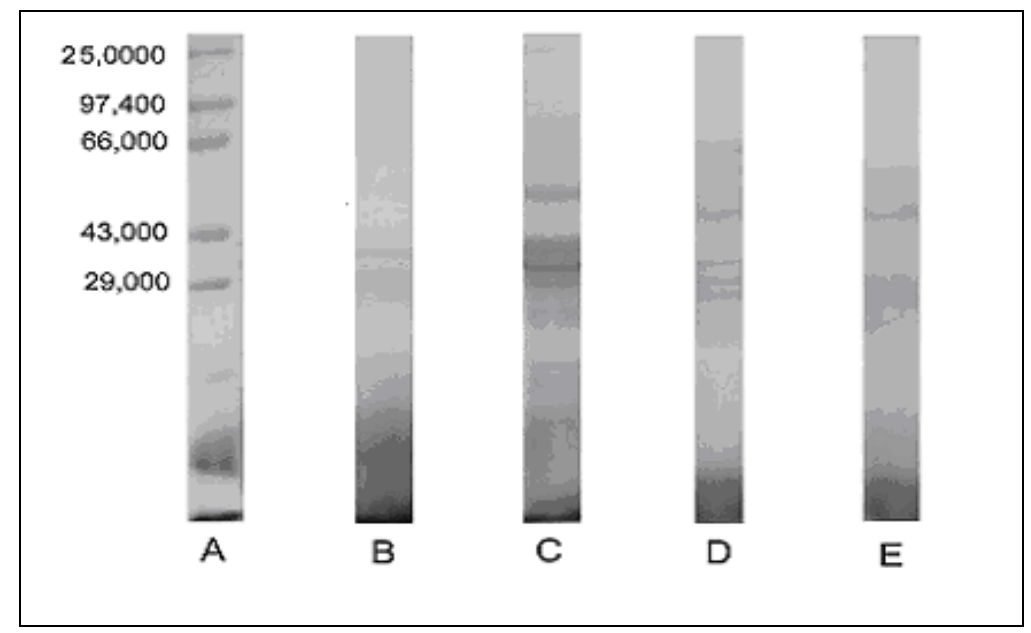

A: Protein molecular weight marker, B: Control muscle, C: Sub lethal muscle, D: Control gill, E: Sub lethal gill.

Figure 1. Electrophoretic protein fractions of the control and heavy metal exposed muscle and gill of the Oreochromis mossambicus 
It is suggested that the occurrence of new protein in the muscle has been transported through blood stream or they could have been synthesized in the muscle. It was inferred that these protein fractions could be stress proteins to over come the toxic effect of heavy metal. Manna and Mukherjee ${ }^{6}$ made similar findings in Tilapia on exposure to radiation, malathion and mercuric chloride.

In the present investigation two protein fractions namely $135 \mathrm{kD}$ and $28.5 \mathrm{kD}$ were absent in the gill tissues of cadmium treated fish. It is said that the heavy metal cadmium might have detracted the proteins. The reduction of proteins could be due to the impact on the protein synthetic pathway ${ }^{7}$ or due to the depletion of reserve proteins to over come to stress caused by heavy metal cadmium, since gills are the vulnerable organ to environmental stress. The above findings have been favoured by $\operatorname{Singh}^{8}$ and Athikesavan ${ }^{9}$.

\section{Conclusions}

The present study showed variations of protein patterns in muscle and gill of O. mossambicus on chronic exposure to sub lethal cadmium. Four new proteins were found in the muscle $(120 \mathrm{kD}, 80 \mathrm{kD}, 62 \mathrm{kD}$ and $37 \mathrm{kD})$ and two protein had been depleted in the gill tissues $135 \mathrm{kD}$ and $28.5 \mathrm{kD}$. Hence any pollutant in the natural water system would affect the health of aquatic organisms even at molecular level. Therefore, all possible measures should be adopted to reduce cadmium dependent fertilizers meant for agricultural purpose.

\section{References}

1. Pillai K G, Water Pollution and Management, Wiley Eastern Limited, 1985, 74-93.

2. FAO, Fish Resp, 1986, 352, 20.

3. Finney D J, Probit Anaysis, Cambridge University press, London, 1964, 333.

4. Laemmli U K, Nature, 1970, 226, 680-685.

5. Bhaqowati A K and Rath B K, Proc. Ind. Nat. Sci. Acad, 1982, 48, 67-72.

6. Manna G K and Mukherjee P K, Press. Cytol. Gene, 1986, 5, 225-235.

7. Orr G L and Downer R C H, Pestic. Biochem. Physiol, 1982, 17, 89.

8. Singh A K, Sharm A and Ehtheshamuddin S, Comp. Physiol. Ecol, 1993,18, 56-59.

9. Athikesavan S, Studies on the impact of heavy metal pollutants (Nickel and Zinc) on bioaccumulation, cytogentics and histological changes of the freshwater fish Hypophthalmichtys molitrix (Valenciennes), Ph. D. Thesis, University of Madras, 2001, 77-78. 


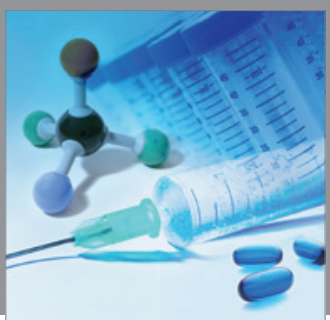

International Journal of

Medicinal Chemistry

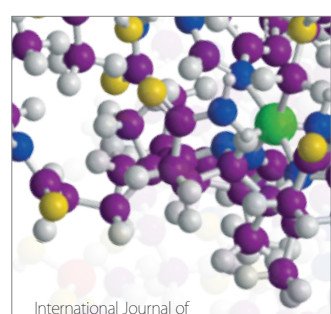

Carbohydrate Chemistry

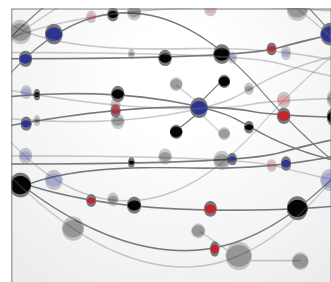

The Scientific World Journal
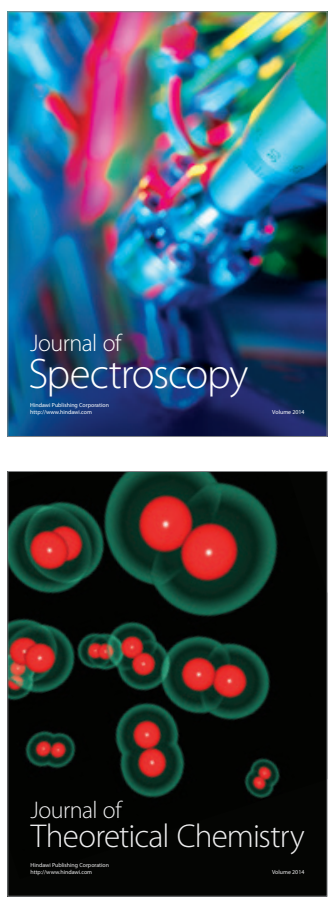
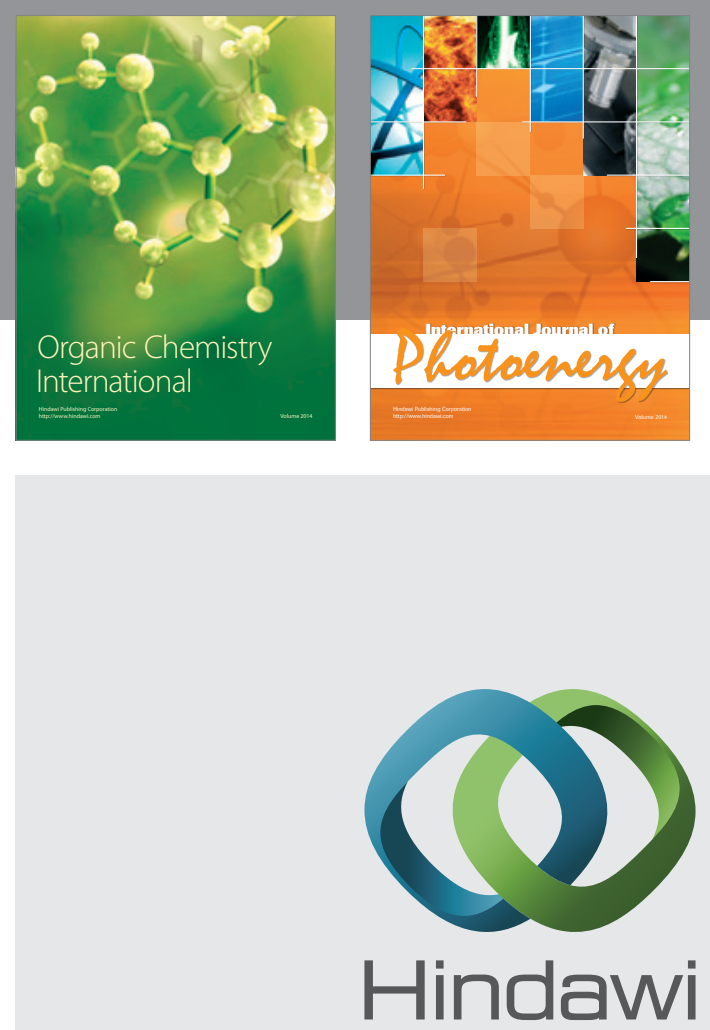

Submit your manuscripts at

http://www.hindawi.com
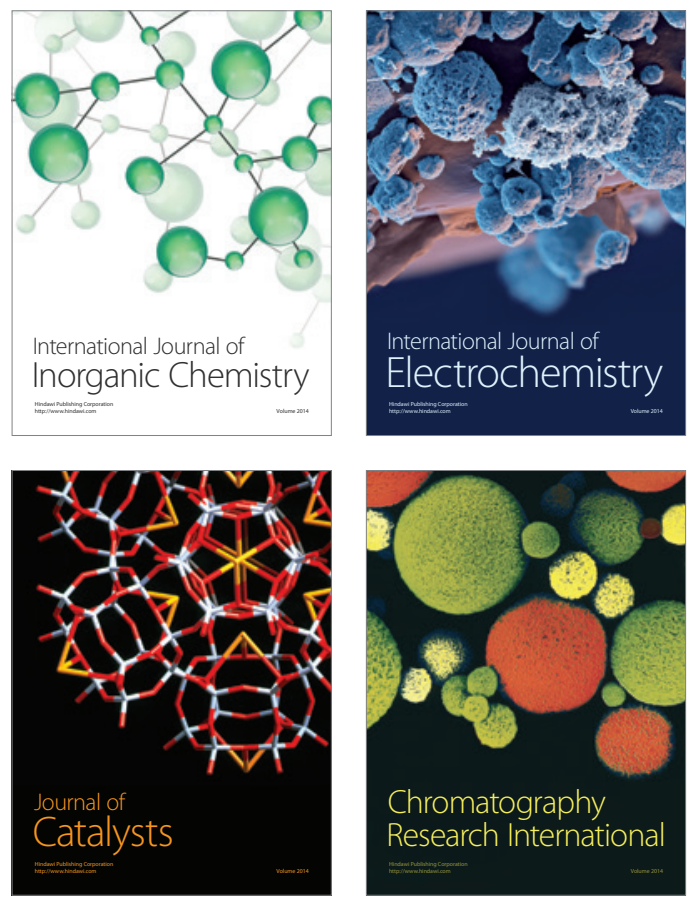
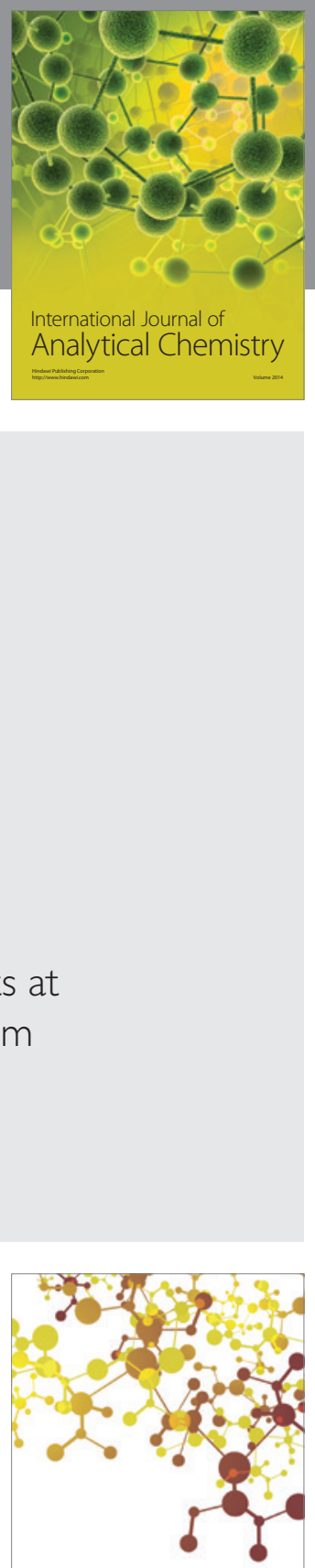

Journal of

Applied Chemistry
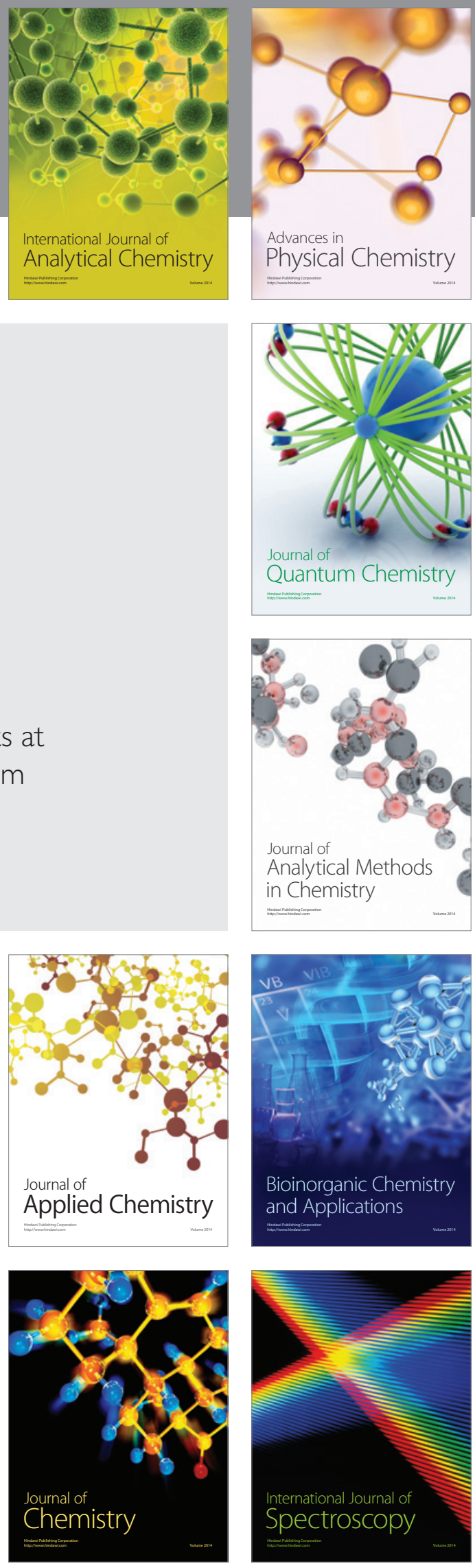